\title{
Quantitative Estimation of Biomass Energy and Evaluation of Biomass Utilization - A Case Study of Jilin Province, China
}

\author{
Junnian Song ${ }^{1}$, Wei Yang ${ }^{1}$, Helmut Yabar $^{1} \&$ Yoshiro Higano ${ }^{1}$ \\ ${ }^{1}$ Graduate School of Life and Environmental Sciences, Tsukuba University, Tsukuba, Japan \\ Correspondence: Song Junnian, Graduate School of Life and Environmental Sciences, Tsukuba University, 1-1-1 \\ Tennodai, Tsukuba, Ibaraki 305-8572, Japan. Tel: 81-80-3365-3120. E-mail: duliry@163.com
}

Received: April 8, 2013 Accepted: April 30, 2013 Online Published: May 30, 2013

doi:10.5539/jsd.v6n6p137 URL: http://dx.doi.org/10.5539/jsd.v6n6p137

\begin{abstract}
Jilin Province, as a large agricultural province, has abundant reserve of biomass resources. At the same time Jilin Province is currently suffering from energy shortage. Besides, consumption of conventional fossil fuels has resulted in the exacerbation of global warming and air pollution. Biomass energy as a renewable and substitutive energy, can mitigate the energy crisis and global warming, and improve environmental quality once it is fully utilized. This paper estimated the supply potential of biomass energy and integrated LCA and environmental cost analysis to make evaluation on biomass utilization taking biomass power generation system as example. Acquirable and utilizable amount of biomass energy in Jilin Province is equivalent to 21.26 tce, which can be accounted for $25.6 \%$ of total energy consumption in Jilin Province in 2011. Among all biomass energy, 59.1\% comes from straw and agricultural residues, followed by $33.8 \%$ from livestock manure. According to the LCA results, total environmental impact of biomass power generation system is 0.721 , much smaller than 25.321 of thermal power generation system. General cost of biomass power generation is higher, however its environmental cost is much lower than thermal power generation system (396 yuan $/ 10^{4} \mathrm{kWh}<1819$ yuan $/ 10^{4} \mathrm{kWh}$ ). The results showed that biomass utilization has better environmental advantages and has the potential for the mitigation of energy crisis in Jilin Province.
\end{abstract}

Keywords: biomass energy, supply potential, biomass power generation, LCA, environmental cost

\section{Introduction}

With the increasingly depletion of conventional and non-renewable energy sources, research on biomass energy, which is a kind of renewable, abundant and environmentally friendly substitutive energy has been a hot issue around the world. Biomass energy is a kind of energy form that converts from solar energy to chemical energy through photosynthesis of green plants directly or indirectly and stored inside biomass (Wang \& Ai, 2006).

Jilin Province, located in the northeast of China, is important industrial base and commodity grain base of China. Along with the acceleration of industrialization and urbanization, energy consumption of Jilin Province is increasing rapidly. Shortage of primary energy, low energy self-sufficiency rate and unreasonable energy structure are urgent problems for Jilin Province to solve. Besides, consumption of conventional fossil fuels has resulted in the exacerbation of global warming and air pollution. Reserve of primary energy of Jilin Province only accounts for $0.3 \%$ of China and its energy self-sufficiency rate is less than $50 \%$ (Zhao, 2011). Energy consumption is increasing continuously and there is large disparity between energy production and consumption. Figure 1 shows energy production and energy consumption of Jilin Province from 2000 to 2010. In 2010, conventional fossil energy accounted for $94.1 \%$ of the total energy consumption and new and renewable energy only accounted for $5.9 \%$. Figure 2 shows the consumption ratio of different kinds of energy. 


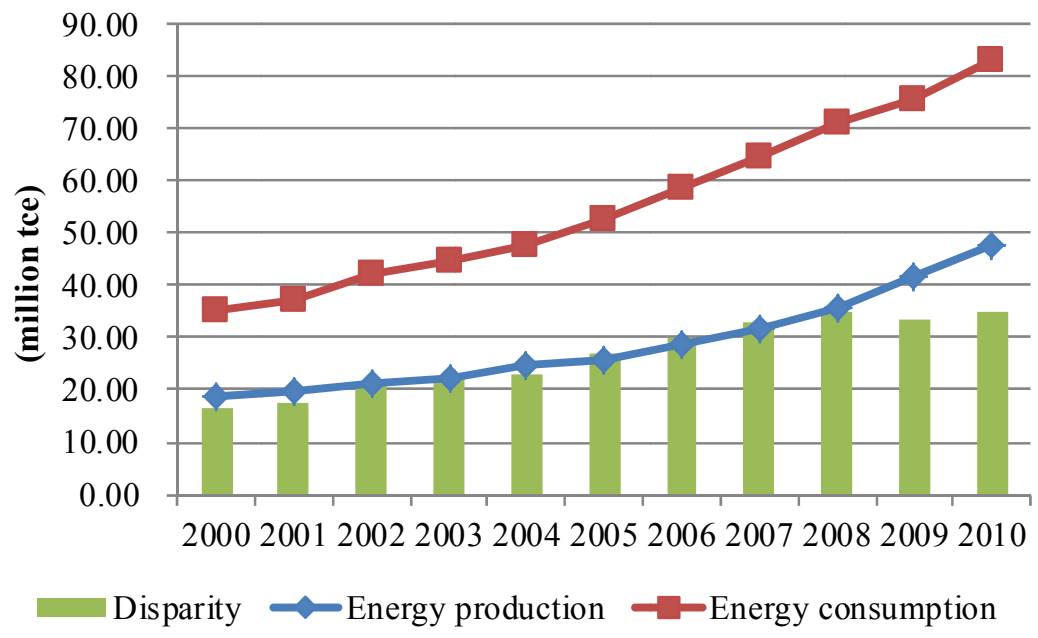

Figure 1. Energy production and consumption of Jilin Province from 2000 to 2010

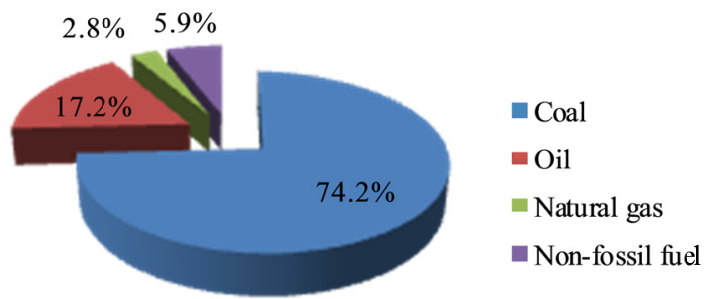

Figure 2. Energy consumption structure of Jilin Province in 2010

As a traditional agricultural province, there are a lot of advantages to support the biomass energy development in Jilin Province. Jilin Province has abundant reserve of biomass resources. Wide arable land, high yield of grain, scaled breeding and forestry industries are providing material basis for the utilization of agroforestry residues and livestock manure. According to the 12th 5-year plan, Jilin Province has proposed a target to raise the biomass energy production to 8.4 million tons of standard coal. The utilization of biomass energy can not only substitute conventional fossil energy to mitigate the energy crisis but also adjust the energy consumption structure to reduce the emission of green house gases and air pollutants.

Currently, domestic and foreign researches regarding evaluation of biomass energy utilization focus on benefit evaluation and policy support of different biomass energy industries. New Energy and Industrial Technology Development Organization of Japan published White-book of Renewable Energy Technologies introducing the biomass resource development potential in Japan and advanced biomass energy technologies (NEDO, 2010). Wang established the lumped weighted evaluation model based on Analytic Hierarchy Process and selected nine evaluation indexes to determine the major affecting factors of biomass utilization (Wang, 2008). Ren established a comprehensive evaluation index system based on non-linear programming for the utilization efficiency of agricultural biomass resources (Ren, 2011). Wenisch firstly analyzed the effect of biomass household biogas to household energy consumption and then analyzed the environmental benefit, economic benefit and social benefit of household biogas with LCA when evaluating the resource benefit of rural waste utilization in Denmark (Wenisch \& Rousseaux, 2004). Thornley and Cooper analyzed the obstacles of biomass energy utilization especially the lack of legislation, economic elements, pricing without consideration of environmental impacts (Thornley \& Cooper, 2008). Few research has been focused on empirical quantitative analysis on biomass utilization and its environmental effects to a specific region.

This article is aimed to estimate the biomass energy potential of Jilin Province quantitatively to show its mitigation capacity for energy shortage and determine the major utilization direction of biomass energy in Jilin Province. Based on the supply potential of biomass energy, evaluation of the environmental impacts and environmental cost of biomass utilization through LCA will be made to show the environmental advantages of 
biomass energy compared with conventional energy taking biomass power generation system in Jilin Province as example.

\section{Materials and Methods}

\subsection{Quantitative Estimation of Biomass Energy Potential}

There are different indexes for the availability evaluation of biomass energy and the amount calculation of organic biomass resources in corresponding to different criterion ( $\mathrm{Li}, \mathrm{Ren}, \&$ Zhuang, 2001). Here three definitions including physical reserve, acquirable and utilizable amount, and equivalent of standard energy are introduced (Liu \& Shen, 2007). The amount of major biomass resources is evaluated step by step according to these three definitions.

\subsubsection{Physical Reserve}

Physical reserve is the total amount of theoretically physical production of major biomass resources from four sources including straw and agricultural residues, firewood and forestry residues, livestock manure and municipal waste.

(1) Straw and agricultural residues

Straw and other agricultural residues mainly come from food crops, cotton, hemp and sugar. Straw-grain ratio method is widely adopted to calculate the amount of crop straw. Straw-grain ratio is the ratio of the amount of stems above the ground and the amount of economic yield of crops. The yield of straw can be calculated by:

$$
C R=\sum_{i=1}^{n} Q c_{i} \times r_{i}
$$

CR: physical amount of straw, $\mathrm{Qc}_{\mathrm{i}}$ : yield of Crop i, $\mathrm{r}_{\mathrm{i}}$ : straw-grain ratio of Crop i. Straw-grain ratios of different crops are shown in Table 1 (Liu, Na, \& Wang, 2010; Bi, 2010).

Table 1. Straw-grain ratio of different crops

\begin{tabular}{cccccccc}
\hline Crops & Rice & Wheat & Corn & Sorghum & Soybean & Sunflower & Hemp \\
\hline Ratio & 1 & 1.3 & 1.32 & 1.6 & 1.16 & 2.8 & 2 \\
\hline
\end{tabular}

\section{(2) Firewood and forestry residues}

Forestry biomass resources mainly derive from clearing, cutting and processing residues of forestry production, firewood forests and forest tending and thinning. The amount of forestry biomass resources can be calculated either with index as area of forests, firewood coefficient and production of per unit area (Yuan, Wu, \& Huang, 2002) or by respectively calculating the amount of firewood forests, residues of forestry production and other forestry biomass (Research Group of Chinese Forest Bio-energy [RGCFB], 2006). This article mainly calculates the amount of forestry residues, firewood forests, forest tending and thinning and the adjacent small trees by:

$$
F R=\sum_{i=1}^{n} Q f_{i} \times r_{i}
$$

FR: physical amount of forestry biomass, $\mathrm{Qf}_{\mathrm{i}}$ : amount of Forestry biomass $\mathrm{i}, \mathrm{r}_{\mathrm{i}}$ : conversion coefficient. Some related conversion coefficients are shown in Table 2 (Yuan et al., 2002; RGCFB, 2006; Shi, 2008).

Table 2. Conversion coefficients of different forestry biomass

\begin{tabular}{cccccc}
\hline $\begin{array}{c}\text { Forestry } \\
\text { biomass }\end{array}$ & $\begin{array}{c}\text { Cutting } \\
\text { residues }\end{array}$ & $\begin{array}{c}\text { Processing } \\
\text { residues }\end{array}$ & $\begin{array}{c}\text { Firewood } \\
\text { forests }\end{array}$ & $\begin{array}{c}\text { Forest tending } \\
\text { and thinning }\end{array}$ & $\begin{array}{c}\text { Adjacent } \\
\text { small trees }\end{array}$ \\
\hline Coefficient & $\begin{array}{c}40 \% \text { of the } \\
\text { cutting } \\
\text { amount }\end{array}$ & $\begin{array}{c}40 \% \text { of the log } \\
\text { amount }\end{array}$ & $100 \%$ & $100 \%$ & $100 \%$ \\
$\begin{array}{c}\text { Weight } \\
\text { conversion }\end{array}$ & $1.17 \mathrm{t} / \mathrm{m}^{3}$ & $0.9 \mathrm{t} / \mathrm{m}^{3}$ & $\begin{array}{c}50 \\
\mathrm{~m}^{3} / \mathrm{hm}^{2}, 1.17 \\
\mathrm{t} / \mathrm{m}^{3}\end{array}$ & $\begin{array}{c}8 \mathrm{~m}^{3} / \mathrm{hm}^{2}, 0.9 \\
\mathrm{t} / \mathrm{m}^{3}\end{array}$ & $\begin{array}{c}2 \mathrm{~kg} / \mathrm{per} \\
\text { plant }\end{array}$ \\
\hline
\end{tabular}




\section{(3) Livestock manure}

The amount of manure is related to species, breeds, genders, growing season and so on (Ding, 2000). Here the livestock is assumed as mature and the breeding cycle is assumed as fixed. The amount of manure can be calculated with daily yields and breeding cycle by:

$$
D=\sum_{i=1}^{n} Q d_{i} \times d_{i} \times m_{i}=\sum_{i=1}^{n} Q d_{i} \times M_{i}
$$

D: physical amount of manure, $\mathrm{Qd}_{\mathrm{i}}$ : the number of Livestock $\mathrm{i}, \mathrm{d}_{\mathrm{i}}$ : daily yield of dry manure of Livestock manure $\mathrm{i}, \mathrm{m}_{\mathrm{i}}$ : breeding cycle, $\mathrm{M}_{\mathrm{i}}$ : manure yield of Livestock $\mathrm{i}$ within the whole breeding cycle. Breeding cycle and manure yield of different livestock and poultry are shown in table 3 (Liu \& Shen, 2007; Ding, 2000; Wang, 1998; Peng \& Wang, 2004).

Table 3. Breeding cycles and manure yields of different livestock and poultry

Unit: day and $\mathrm{kg}$

\begin{tabular}{ccccccccc}
\hline Livestock & Hogs & Herds hogs & Cattle & Cows & Sheep & Horse & Jennets & Poultry \\
\hline Breeding cycle & 300 & 365 & 365 & 365 & 365 & 365 & 365 & 55 \\
Manure yields & 1050 & 1460 & 8200 & 21900 & 632 & 5237 & 3092 & 4.5 \\
\hline
\end{tabular}

(4) Municipal waste

Municipal waste consists of municipal solid waste and municipal waste water. Municipal solid waste can be divided into organic waste and inorganic waste according to the composition. The organic waste can be utilized as biomass resources. Municipal waste water is divided into domestic sewage and industrial wastewater, both can be treated to produce biogas. The amount of total municipal waste can be calculated by:

$$
M W=S W \times r_{1}+Q W \times r_{2}
$$

SW: the amount of municipal solid waste, $\mathrm{r}_{1}$ : the percentage of organic waste from municipal solid waste, Qw: the amount of waste water, $\mathrm{r}_{2}$ : the percentage of COD in waste water.

\subsubsection{Acquirable and Utilizable Amount}

Physical reserve of biomass resources is the amount representing the theoretically richest developing potential (LIU \& SHEN, 2007). Not all the reserve can be acquired and utilized to produce energy. There is availability coefficient and utilization coefficient of biomass resources for energy generation. The acquirable and utilizable amount refers to the amount of biomass resources that can be acquired and utilized to produce energy under theoretical conditions. It can be calculated from the amount of physical reserve.

$$
C R^{\prime}=\sum_{i=1}^{n} Q c_{i} \times r_{i} \times \lambda_{i} \times \delta_{i}
$$

CR': acquirable and utilizable amount of straw, $\lambda_{\mathrm{i}}$ : availability coefficient of Crop i. $\delta_{\mathrm{i}}$ : utilization coefficient. Acquirable and utilizable amount of forestry residues (FR'), livestock manure (D') and municipal waste (MW') can be calculated with corresponding $\lambda_{\mathrm{i}}$ and $\delta_{\mathrm{i}}$. Availability coefficient of all kinds of biomass resources is the collection ratio and determined according to local conditions and the average value will be adopted. The ratio of straw amount utilized as household fuel and discarded or combusted can be considered as energy production and is determined as $80 \%$. About $1 / 3$ of forestry residues and livestock manure can be utilized to produce energy. About $60 \%$ of municipal solid waste can be utilized through combustion and compost. About $50 \%$ of municipal waste water can be utilized to produce biogas. Table 4 concludes the availability coefficient and utilization coefficient of different biomass resources (Liu \& Shen, 2007; Liu et al., 2010; RGCFB, 2006; Yuan, Wu \& Ma, 2005; National Development and Reform Commission-Energy Research Institute [NDRCERI], 2010; Milbrandt, 2005). 
Table 4. Availability coefficient and utilization coefficient of different biomass resources $\left(\lambda_{\mathrm{i}}\right.$ and $\left.\delta_{\mathrm{i}}\right)$

\begin{tabular}{cccccc}
\hline Types & Straw & $\begin{array}{c}\text { Forestry } \\
\text { residues }\end{array}$ & $\begin{array}{c}\text { Livestock } \\
\text { manure }\end{array}$ & $\begin{array}{c}\text { Municipal solid } \\
\text { waste }\end{array}$ & $\begin{array}{c}\text { Municipal waste } \\
\text { water }\end{array}$ \\
\hline $\begin{array}{c}\text { Availability } \\
\text { coefficient }\left(\lambda_{\mathrm{i}}\right)\end{array}$ & $90 \%$ & $40 \%$ & $60 \%$ & $40 \%$ & $100 \%{ }^{*}$ \\
$\begin{array}{c}\text { Utilization } \\
\text { coefficient }\left(\delta_{\mathrm{i}}\right)\end{array}$ & $80 \%$ & $1 / 3$ & $1 / 3$ & $60 \%$ & $50 \%$
\end{tabular}

*The data of the amount of municipal waste water collected from statistical year book can be considered as the acquirable amount, therefore the availability coefficient is determined as $100 \%$.

\subsubsection{Equivalent of Standard Energy}

When put into unified and practical studies, biomass energy is usually accounted to the equivalent of standard energy, which is generally standard coal equivalent. In terms of the calculation of straw standard energy (ECR), conversion coefficient $\eta_{i}$ is introduced into the calculation as:

$$
E C R=\sum_{i=1}^{n} Q c_{i} \times r_{i} \times \lambda_{i} \times \delta_{i} \times \eta_{i}
$$

As for the calculation of forestry residues standard energy equivalent (EFR), livestock manure standard energy equivalent (ED) and municipal waste standard energy equivalent (EMW), corresponding $\eta_{i}$ should be introduced. When waste water is converted to standard energy equivalent, it is firstly converted to biogas $\left(0.907 \mathrm{~m}^{3}\right.$ biogas can be generated from $1 \mathrm{~kg}$ COD) (Milbrandt, 2005). Table 5 concludes conversion coefficient of different types of biomass resources (Liu \& Shen, 2007).

Table 5. Conversion coefficient of standard energy of different biomass resources $\left(\eta_{\mathrm{i}}\right)$ Unit: biogas, $\mathrm{kgce} / \mathrm{m}^{3}$; others, $\mathrm{kgce} / \mathrm{kg}$

\begin{tabular}{cc}
\hline Types of livestock and poultry & Coefficient \\
\hline Rice straw & 0.429 \\
Wheat straw & 0.500 \\
Corn straw & 0.529 \\
Sorghum straw & 0.050 \\
Soybean straw & 0.543 \\
Sunflower straw & 0.529 \\
Hemp straw & 0.500 \\
Firewood & 0.571 \\
Hog manure & 0.429 \\
Cattle manure & 0.471 \\
Poultry manure & 0.643 \\
Horse, sheep and jennet manure & 0.529 \\
Municipal solid waste & 0.143 \\
Biogas & 0.857 \\
\hline
\end{tabular}

\subsection{Life Cycle Environmental Impact Assessment of Biomass Power Generation System}

Life Cycle Assessment (LCA) is a tool used to assess the impacts on environment brought by products or conduct during the life cycle. LCA can identify and quantify the utilization of energy and materials and the emission of wastes; assess the impact extent of the utilization and emission and strive to seek the chance to improve the environmental quality (Liu \& Wang, 2008). 
This part is a case study that associates LCA and cost analysis to make comprehensive evaluation on biomass utilization taking a biomass power generation system in Jilin Province as example.

\subsubsection{Introduction of Biomass Power Generation System}

(1) Introduction of the study object

Songyuan City is a new petrochemical city located in the west of Jilin Province. It is large commodity grain base and oil base of China whose yield of corn is 4 million ton, accounting for 1/4 of Jilin Province's total yield. The government deployed the overall route of straw power generation to construct Datang Songyuan biomass power generation project in Songyuan City to develop and promote biomass utilization.

The study object of this research is $15 \mathrm{MW}$ ( 2 sets) straw direct-fired power generation system, whose annual electricity generation time is $6000 \mathrm{~h}$ and rated annual generating capacity is $1.8 \times 10^{8} \mathrm{kWh}$. Environmental impacts brought by $10000 \mathrm{kWh}$ of power generation will be calculated and analyzed, which means the functional unit of the system is $10000 \mathrm{kWh}$. Main processes of the system include feedstock collection, straw combustion, water recycling and purification, and power generation.

(2) Sources of straw

There are 0.76 million $\mathrm{hm}^{2}$ of farmlands in Songyuan City. Total yield of corn in normal year is 5 million ton. Within the scope of $25 \mathrm{~km}$ radius, yield of corn straw is 0.691 million $\mathrm{t} / \mathrm{a}$, of which $65 \%$ is discarded. Calculated by this proportion, corn straw that can be used as fuel for power generation is 0.449 million $\mathrm{t} / \mathrm{a}$.

Table 6. Straw consumption of the plant

\begin{tabular}{cccc}
\hline Boiler & Consumption per hour $(\mathrm{t} / \mathrm{h})$ & Consumption per day $(\mathrm{t} / \mathrm{d})$ & Consumption per year $\left(10^{6} \mathrm{t} / \mathrm{a}\right)$ \\
\hline $1 \times 75 \mathrm{t} / \mathrm{h}$ & 17.0 & 374.0 & 0.102 \\
$2 \times 75 \mathrm{t} / \mathrm{h}$ & 34.0 & 748.0 & 0.204 \\
\hline
\end{tabular}

Table 6 shows straw consumption of the plant. Fuel demand of the plant is 0.204 million t/a. So the supply amount can satisfy the fuel demand of the power generation system.

\subsubsection{Assessment Scope and Boundary Demarcation}

When determining the assessment boundary, some points should be considered: (1) In order to form a closed loop system, the coal, oil, electricity, steel and water consumed during construction period of the plant are not involved into the boundary; (2) Because biomass power generation system is a new system that has not reached the scrapping age, equipment recovery unit is not considered. (Liu, 2010) Based on the assumptions above, biomass power generation system can be divided into three parts: (1) Agricultural production period; (2) Transportation period; (3) Plant operational period. Figure 3 shows the life cycle boundary and frame of the power generation system.

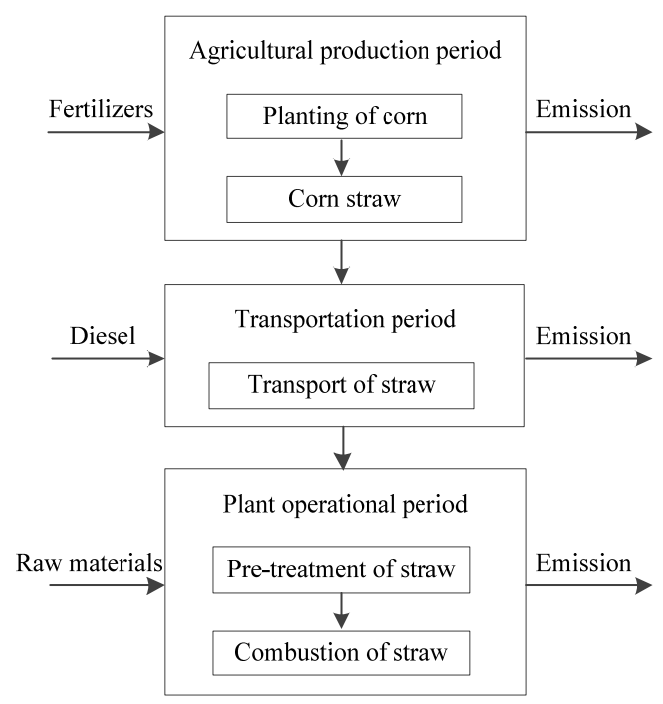

Figure 3. Life cycle boundary and frame of the power generation system 


\subsubsection{Inventory Analysis}

Inventory analysis is to quantify and assess the processes of energy and resources consumption and environmental release during life cycle of the system. The raw materials and energy consumed is determined as input inventory and the substances (including waste gases, waste water and solid waste etc.) emitted into environment from all processes of the system is determined as output inventory.

(1) Agricultural production period

Emissions from agricultural production has three sources: (1) Pollutant emission from mechanical use; (2) Pollutant emission from fertilizer use; (3) Emission of nitrogen fertilizer loss due to inefficient use of fertilizers. In life cycle inventory analysis, there should be distribution of energy flow and pollutant emission for the system that has various kinds of output. During planting process of corn, straw is by-product. According to the economic value, energy consumption and pollutant emission of corn straw account for $10 \%$ of the whole energy flow and pollutant emission of the planting process of corn. Calculated by this proportion, emission amount of pollutants from corn straw consumed by the plant in one year can be obtained and shown in Table 7 (Liang, Chen, \& Gao, 2009).

Table 7. Emission amount of pollutants during agricultural production period

Unit: $\mathrm{t} / \mathrm{a}$

\begin{tabular}{cccccccc}
\hline Pollutants & $\mathrm{CO}_{2}$ & $\mathrm{CO}$ & $\mathrm{CH}_{4}$ & $\mathrm{~N}_{2} \mathrm{O}$ & NOx & Dust & $\mathrm{SO}_{2}$ \\
\hline Emission amount & 13916.88 & 33.72 & 10.98 & 4.96 & 63.51 & 0.18 & 125.62 \\
\hline
\end{tabular}

\section{(2) Transportation period}

The transportation radius is within $25 \mathrm{~km}$. 9 collection stations will be established around the power generation plant. Because the binding of straw is mostly done manually, consumption of this period is mainly fuel consumption of transportation tools. Pollutant emission is mainly from exhaust of diesel vehicles. According to the distances between collection stations and the plant, average transportation radius can be determined as $25 \mathrm{~km}$ and the transportation tool is determined as agricultural diesel vehicle whose load is 5 ton. Emission amount of pollutants during transportation period can be calculated with diesel consumption and emission coefficient. The results are shown in Table 8 (Hu, 2006).

Table 8. Emission amount of pollutants during feedstock transportation period

\begin{tabular}{cccccccc}
\hline Pollutants & $\mathrm{CO}$ & Dust & $\mathrm{NOx}$ & $\mathrm{SOx}$ & $\mathrm{CO}_{2}$ & $\mathrm{CH}_{4}$ & $\mathrm{~N}_{2} \mathrm{O}$ \\
\hline Emission coefficient (g/GJ) & 435.651 & 16.337 & 762.390 & 93.665 & 73623.755 & 5.870 & 2.929 \\
Emission amount(t/a) & 21.87 & 0.82 & 38.27 & 4.70 & 3695.91 & 0.29 & 0.15 \\
\hline
\end{tabular}

(3) Plant operational period

During plant operational period, diesel is the major combustion accelerant and electricity is consumed. Pollutants including waste gases, waste water and solid waste are from the following production links: 
Table 9. Pollutant generation links of plant operation

\begin{tabular}{|c|c|c|c|c|c|}
\hline \multicolumn{2}{|c|}{ Types of pollutants } & \multirow{2}{*}{$\begin{array}{c}\text { Source } \\
\begin{array}{c}\text { Straw } \\
\text { combustion }\end{array}\end{array}$} & \multirow{2}{*}{$\begin{array}{c}\begin{array}{c}\text { Major } \\
\text { pollutants }\end{array} \\
\mathrm{SO}_{2}, \mathrm{NOx} \\
\mathrm{HCL} \text {, dust }\end{array}$} & \multirow{2}{*}{$\begin{array}{c}\begin{array}{c}\text { Discharge } \\
\text { pattern }\end{array} \\
\text { Continuous }\end{array}$} & \multirow{2}{*}{$\begin{array}{l}\text { Disposition } \\
\text { Atmosphere }\end{array}$} \\
\hline $\begin{array}{l}\text { Waste } \\
\text { gases }\end{array}$ & Boiler gases & & & & \\
\hline \multirow{4}{*}{$\begin{array}{l}\text { Waste } \\
\text { water }\end{array}$} & $\begin{array}{l}\text { Recycling } \\
\text { sewage }\end{array}$ & $\begin{array}{c}\text { Circular } \\
\text { cooling system }\end{array}$ & Salts, COD & Continuous & Direct reuse \\
\hline & $\begin{array}{l}\text { Acid-alkali } \\
\text { waste water }\end{array}$ & $\begin{array}{l}\text { Chemical } \\
\text { treatment }\end{array}$ & $\mathrm{pH}, \mathrm{COD}$ & Discontinuous & $\begin{array}{l}\text { Municipal pipe } \\
\text { after treatment }\end{array}$ \\
\hline & Boiler sewage & Boiler cleaning & $\mathrm{pH}$, salts, SS & Discontinuous & $\begin{array}{l}\text { Circular system } \\
\text { after treatment }\end{array}$ \\
\hline & $\begin{array}{l}\text { Industrial } \\
\text { waste water }\end{array}$ & Pump cooling & Oil, SS & Continuous & $\begin{array}{l}\text { Circular system } \\
\text { after treatment }\end{array}$ \\
\hline $\begin{array}{l}\text { Solid } \\
\text { waste }\end{array}$ & Straw ashes & Boiler & Solid waste & Discontinuous & $\begin{array}{l}\text { Fertilizer } \\
\text { production }\end{array}$ \\
\hline
\end{tabular}

Table 10. Types and emission amount of the waste gases during plant operational period

\begin{tabular}{ccccc}
\hline Emission index & $\mathrm{SO}_{2}$ & NOx & Dust & $\mathrm{HCL}$ \\
\hline Concentration $\left(\mathrm{mg} / \mathrm{m}^{3}\right)$ & 226.225 & 400 & 23.135 & 52 \\
Amount (t/a) & 250.614 & 443.124 & 25.629 & 57 \\
\hline
\end{tabular}

Types of waste gases and emission amount are shown in Table 10. Waste water from all discharge links is either reused or discharged into municipal pipe network after treatment. The discharge concentration can reach the standard and has little impact on environment. So when calculating environmental impact potential, water environmental impacts can be neglected. Wangsheng Fertilizer Company will purchase all the straw ashes to produce organic fertilizers. So all the ashes will be reused and their environmental impacts can be neglected.

(4) Inventory summary

Considering the close carbon cycle, here is a crucial premise that the amount of $\mathrm{CO}_{2}$ generated during plant operational period is equivalent to that absorbed by corn during growing process (Zhang, 2002). What brings impacts to environment is mainly air pollutants. According to the annual emission amount of pollutants and the annual amount of electricity generation, emission amount of pollutants of 1 functional unit can be calculated as is shown in Table 11.

Table 11. Inventory of life cycle emission of biomass power generation system per functional unit Unit: $\mathrm{kg} / 10^{4} \mathrm{kWh}$

\begin{tabular}{ccccc}
\hline Pollutants & $\begin{array}{c}\text { Agricultural production } \\
\text { period }\end{array}$ & $\begin{array}{c}\text { Transportation } \\
\text { period }\end{array}$ & $\begin{array}{c}\text { Plant operational } \\
\text { period }\end{array}$ & $\begin{array}{c}\text { Total } \\
\text { amount }\end{array}$ \\
\hline $\mathrm{CO}_{2}$ & 773.160 & 205.328 & 0.000 & 978.488 \\
$\mathrm{CO}$ & 1.873 & 1.215 & 0.000 & 3.088 \\
$\mathrm{CH}_{4}$ & 0.610 & 0.016 & 0.000 & 0.626 \\
$\mathrm{~N}_{2} \mathrm{O}$ & 0.276 & 0.008 & 0.000 & 0.284 \\
$\mathrm{NOx}$ & 3.528 & 1.826 & 24.618 & 29.972 \\
$\mathrm{Dust}$ & 0.010 & 0.046 & 1.479 & 1.535 \\
$\mathrm{SO}_{2}$ & 6.979 & 0.261 & 13.923 & 21.163 \\
\hline
\end{tabular}




\subsubsection{Calculation of Environmental Impact Potential}

This part will quantify environmental impacts brought by energy consumption and pollutant emission of the power generation system to lay the foundation of evaluation and improvement of the system. According to the life cycle inventory, five environmental impacts caused by the pollutant emission including Global Warming, Acidification, Photochemical Ozone Creation, Health Toxicity and Solid Waste will be analyzed.

(1) Environmental impact potential

Environmental impact potential refers to the sum of all the impacts of similar pollutant emission within the system. Similar pollutants can be converted to reference's environmental impact potential with equivalent coefficient. Calculation formula of environmental impact potential is:

$$
E P(m)=\sum E P(m) n=\sum[Q(m) n \times E F(m) n]
$$

EP(m): Environmental impact potential m, EP(m)n: Environmental impact potential $m$ of Pollutant $n, Q(m) n$ : emission amount of Pollutant n, EF(m)n: coefficient of Environmental impact potential $m$ of Pollutant $n$.

\section{(2) Standardization}

Standardization of data is to make environmental impact potential dimensionless. The standardized data can intuitively and exactly reflect the environmental impacts of the biomass power generation system. This article chooses the environmental impact potential per capita of the whole society in 1990 as the norm of the standardization. According to the concept of standard human equivalent (the environmental impact potential caused by per capita annually) established by Yang Jianxin (Yang, Xu, \& Wang, 2002), the unit of normalized environmental impact potential is standard human equivalent ( $\left.\mathrm{PE}_{\mathrm{China}}, 1990\right)$. The calculation formula is:

$$
N P(m)=E P(m) / E R(m)
$$

$\mathrm{NP}(\mathrm{m})$ : Standardized environmental impact potential $\mathrm{m}, \mathrm{EP}(\mathrm{m})$ : Environmental impact potential $\mathrm{m}$ of the system, ER(m): standardization norm. Standardization norm of environmental impacts is shown in Table 12.

Table 12. Standardization norm of environmental impacts

\begin{tabular}{cc}
\hline Environmental impact potential & Standardization norm \\
\hline Global Warming Potential (GWP) & $8700 \mathrm{kgCO}_{2} \mathrm{eq}$ \\
Acidification Potential (AP) & $36 \mathrm{kgSO}_{2} \mathrm{eq}$ \\
Photochemical Ozone Creation Potential (POCP) & $0.65 \mathrm{kgC}_{2} \mathrm{H}_{4} \mathrm{eq}$ \\
Health Toxicity Potential (HTP) & $18 \mathrm{~kg}$ \\
Solid Waste Potential (SWP) & $18 \mathrm{~kg}$ \\
\hline
\end{tabular}

(3) Weighted assessment

Standardization cannot compare the relative seriousness of different environmental impacts. It is necessary to make the sequence of the seriousness of different environmental impact potential by endowing different weights to the extent of environmental damage. The calculation formula is:

$$
W P(m)=W F(m) \times N P(m)
$$

$\mathrm{WP}(\mathrm{m})$ : Weighted environmental impact potential $\mathrm{m}, \mathrm{WF}(\mathrm{m})$ : weight of Environmental impact potential $\mathrm{m}$, $\mathrm{NP}(\mathrm{m})$ : Standardized environmental impact potential $\mathrm{m}$.

This paper mainly analyzes five environmental impacts and adopts Analytic Hierarchy Process (AHP) to analyze the relative importance of the five environmental impacts to determine the weights of them. The judging matrix of nine-scale analysis is adopted as is shown in Table 13. 
Table 13. The judging matrix of nine-scale analysis

\begin{tabular}{cccccc}
\hline \multicolumn{1}{c}{$\mathrm{a}_{\mathrm{ij}}$} & $\begin{array}{c}\text { Global } \\
\text { Warming }\end{array}$ & Acidification & $\begin{array}{c}\text { Photochemical } \\
\text { Ozone Creation }\end{array}$ & $\begin{array}{c}\text { Health } \\
\text { Toxicity }\end{array}$ & $\begin{array}{c}\text { Solid } \\
\text { Waste }\end{array}$ \\
\hline Global Warming & 1 & 3 & 6 & 5 & 4 \\
Acidification & $1 / 3$ & 1 & 5 & 3 & 3 \\
Photochemical & $1 / 6$ & $1 / 5$ & 1 & $1 / 4$ & $1 / 2$ \\
Ozone Creation & $1 / 5$ & $1 / 3$ & 4 & 1 & 2 \\
Health Toxicity & $1 / 4$ & $1 / 3$ & 2 & $1 / 2$ & 1 \\
Solid Waste & $1 / 3$ & & \\
\hline
\end{tabular}

According to the judging matrix,

$$
\begin{gathered}
q_{i j}=a_{i j} / \sum_{k=1}^{m} a_{k j} \\
\alpha_{i}=\sum_{j=1}^{m} q_{i j} \\
w_{i}=\alpha_{i} / \sum_{k=1}^{m} \alpha_{k} \\
\lambda_{\max }=\frac{1}{m} \sum_{i=1}^{m} \frac{(A W)_{i}}{w_{i}}
\end{gathered}
$$

The weight vector is $\mathrm{W}=\left(\mathrm{w}_{1}, \mathrm{w}_{2}, \ldots, \mathrm{w}_{\mathrm{m}}\right)^{\mathrm{T}}=(0.48,0.25,0.05,0.13,0.09)^{\mathrm{T}}$. The largest eigenvalue is $\lambda_{\max }=5.222$.

$$
C I=\frac{\lambda_{\max }-m}{m-1}
$$

The Consistency Index, CI can be calculated as 0.056 . The Random index, RI is 1.13 according to random index table. The Consistency Rate, $\mathrm{CR}=\mathrm{CI} / \mathrm{RI}=0.0459<0.1$ (according to average random consistent index, when $\mathrm{m}>=3$, $\mathrm{CR}<0.1$, consistency can meet the requirement), so the consistency can be accepted.

\subsection{Life Cycle Cost Analysis}

In order to stress the environmental advantages of biomass power generation system, this article calculates the external environmental cost of biomass power generation system and involves it into life cycle cost analysis.

(1) General cost analysis

General cost mainly consists of the consumption cost of raw materials and energy, operational cost, transportation cost, investment cost, depreciation cost and tax cost. Table 14 shows the economic evaluation of biomass power generation system. 
Table 14. Economic evaluation of biomass power generation system

\begin{tabular}{ccc}
\hline Items & Unit & Value \\
\hline Total investment & $10^{3}$ yuan & 288,730 \\
Static investment & $10^{3}$ yuan & 255,300 \\
Dynamic investment & $10^{3}$ yuan & 266,670 \\
Operation years & years & 20 \\
Operation time & $\mathrm{h} / \mathrm{a}$ & 6,000 \\
Total electricity generation & $\mathrm{GWh}$ & 211 \\
Price of corn straw & yuan/t & 250 \\
Quantity of corn straw & $10^{3} \mathrm{t}$ & 204 \\
Fuel cost & $10^{3}$ yuan & 51,000 \\
Labor cost & $10^{3}$ yuan & 4,000 \\
Maintenance cost & $10^{3}$ yuan & 6,000 \\
Materials cost & $10^{3}$ yuan & 12,000 \\
Management cost & $10^{3}$ yuan & 1,500 \\
Depreciation cost & $10^{3}$ yuan & 15,000 \\
\hline
\end{tabular}

(2) Environmental cost analysis

External environmental cost of biomass power generation system refers to the value converts from the impacts caused by pollutants during the whole life cycle. The conversion is according to current environmental costs of all kinds of pollutants. Taking reference of the Pollution Charge Standard (PSC) of China and the Environmental Value Standard of the USA (U.S.EVS) (Huang, 2008), the standard measurement of environmental value of different pollutants can be shown in Table 15 .

Table 15. Standard measurement of environmental value

\begin{tabular}{cccccc}
\hline Pollutant & $\mathrm{CO}_{2}$ & $\mathrm{CO}$ & $\mathrm{NOx}$ & $\mathrm{SO}_{2}$ & $\mathrm{PM}_{10}$ \\
\hline Environmental value & 0.023 & 1 & 8 & 6 & 2.2 \\
\hline
\end{tabular}

Unit: yuan $/ \mathrm{kg}$

The calculation formula is:

$$
L C E C=\sum Q(n) \times E V(n)
$$

LCEC: Life cycle environmental cost, Q(n): emission amount of Pollutant n, EV(n): Environmental value of Pollutant $n$.

\section{Results and Discussion}

\subsection{Results of Biomass Energy Potential in Jilin Province}

With the calculation analysis and data summary (collected from Statistical Yearbook of Jilin Province 2011), results of physical reserves, acquirable and utilizable amount and equivalent of standard energy are obtained and shown in Table 16. 
Table 16. Results summary of organic biomass energy in Jilin Province

\begin{tabular}{ccccc}
\hline Types & $\begin{array}{c}\text { Physical } \\
\text { reserves }\left(10^{6} \mathrm{t}\right)\end{array}$ & $\begin{array}{c}\text { Acquirable and } \\
\text { utilizable amount } \\
\left(10^{6} \mathrm{t}\right)\end{array}$ & $\begin{array}{c}\text { Standard energy } \\
\text { equivalent }\left(10^{6} \mathrm{tce}\right)\end{array}$ & Percentage \\
\hline $\begin{array}{c}\text { Straw and } \\
\text { agricultural residues }\end{array}$ & 35.04 & 25.23 & 12.58 & $59.1 \%$ \\
$\begin{array}{c}\text { Firewood and } \\
\text { forestry residues }\end{array}$ & 11.00 & 1.47 & 0.84 & $3.9 \%$ \\
$\begin{array}{c}\text { Livestock manure } \\
\text { Municipal waste }\end{array}$ & 78.01 & 15.60 & 7.19 & $33.8 \%$ \\
In total & 5.58 & 3.29 & 0.66 & $3.1 \%$ \\
\hline
\end{tabular}

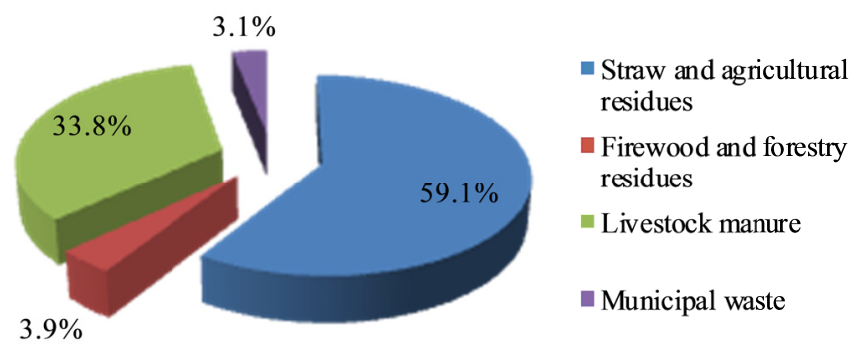

Figure 4. Amount composition of various biomass energy

The results show that total amount of biomass energy in Jilin Province is 21.26 million tce, among which 59.1\% comes from farming, 33.8\% comes from animal husbandry, 3.9\% comes from forestry and 3.1\% comes from city. The total amount of biomass energy can be accounted for $25.6 \%$ of total energy consumption of Jilin Province in 2011. Compared with the disparity of energy production and consumption in 2010 in Jilin Province (35.07 million tce), once the biomass energy is fully developed and utilized, it can facilitate to the mitigation of severe energy crisis in Jilin Province. Farming is the biggest source of biomass energy in Jilin Province providing a advantageous condition for the utilization of straw. So there should be a priority for the utilization of straw and agricultural residues.

\subsection{Life Cycle Environmental Impact Assessment of Biomass Power Generation System}

\subsubsection{Results of Environmental Impact Potential}

Calculation results of all life cycle environmental impact potential, standardization results and weighted assessment results are shown in Table 17 to Table 19. 
Table 17. Results of life cycle environmental impact potential

\begin{tabular}{|c|c|c|c|c|c|c|}
\hline $\begin{array}{l}\text { Environmental } \\
\text { impact } \\
\text { potential }\end{array}$ & Pollutants & $\begin{array}{l}\text { Equivalent } \\
\text { coefficient }\end{array}$ & $\begin{array}{l}\text { Agricultural } \\
\text { production } \\
\text { period }\end{array}$ & $\begin{array}{l}\text { Transportation } \\
\text { period }\end{array}$ & $\begin{array}{l}\text { Plant } \\
\text { operational } \\
\text { period }\end{array}$ & In total \\
\hline \multirow{4}{*}{$\begin{array}{l}\mathrm{GWP} \\
\left(\mathrm{kgCO}_{2} \mathrm{eq}\right)\end{array}$} & $\mathrm{CO}_{2}$ & 1 & \multirow{4}{*}{880.334} & \multirow{4}{*}{210.828} & \multirow{4}{*}{0.000} & \multirow{4}{*}{1091.162} \\
\hline & $\mathrm{CO}$ & 2 & & & & \\
\hline & $\mathrm{CH}_{4}$ & 25 & & & & \\
\hline & $\mathrm{N}_{2} \mathrm{O}$ & 320 & & & & \\
\hline \multirow{2}{*}{$\begin{array}{l}\mathrm{AP} \\
\left(\mathrm{kgSO}_{2} \mathrm{eq}\right)\end{array}$} & NOx & 0.7 & \multirow{2}{*}{9.449} & \multirow{2}{*}{1.539} & \multirow{2}{*}{31.155} & \multirow{2}{*}{42.143} \\
\hline & $\mathrm{SO}_{2}$ & 1 & & & & \\
\hline \multirow{2}{*}{$\begin{array}{l}\text { POCP } \\
\left(\mathrm{kgC}_{2} \mathrm{H}_{4} \mathrm{eq}\right)\end{array}$} & $\mathrm{CO}$ & 0.03 & \multirow{2}{*}{0.060} & \multirow{2}{*}{0.037} & \multirow{2}{*}{0.000} & \multirow{2}{*}{0.097} \\
\hline & $\mathrm{CH}_{4}$ & 0.007 & & & & \\
\hline \multirow{3}{*}{$\begin{array}{l}\text { HTP } \\
(\mathrm{kg})\end{array}$} & $\mathrm{CO}$ & 0.012 & \multirow{3}{*}{11.149} & \multirow{3}{*}{1.752} & \multirow{3}{*}{35.909} & \multirow{3}{*}{48.811} \\
\hline & NOx & 0.78 & & & & \\
\hline & $\mathrm{SO}_{2}$ & 1.2 & & & & \\
\hline $\begin{array}{l}\text { SWP } \\
(\mathrm{kg})\end{array}$ & Smoke\&dust & 1 & 0.010 & 0.046 & 1.479 & 1.535 \\
\hline
\end{tabular}

Table 18. Standardized results of life cycle environmental impact potential

\begin{tabular}{ccccc}
\hline $\begin{array}{c}\text { Environmental } \\
\text { impact } \\
\text { potential }\end{array}$ & $\begin{array}{c}\text { Agricultural } \\
\text { production } \\
\text { period }\end{array}$ & $\begin{array}{c}\text { Transportation } \\
\text { period }\end{array}$ & $\begin{array}{c}\text { Plant } \\
\text { operational } \\
\text { period }\end{array}$ & $\begin{array}{c}\text { In } \\
\text { total }\end{array}$ \\
\hline GWP & 0.101 & 0.024 & 0.000 & 0.125 \\
AP & 0.262 & 0.043 & 0.865 & 1.171 \\
POCP & 0.092 & 0.057 & 0.000 & 0.149 \\
HTP & 0.619 & 0.097 & 1.995 & 2.712 \\
SWP & 0.001 & 0.003 & 0.082 & 0.085 \\
\hline
\end{tabular}

Table 19. Weighted assessment results of life cycle environmental impact potential

\begin{tabular}{cccccc}
\hline $\begin{array}{c}\text { Environmental } \\
\text { impact } \\
\text { potential }\end{array}$ & Weight & $\begin{array}{c}\text { Agricultural } \\
\text { production } \\
\text { period }\end{array}$ & $\begin{array}{c}\text { Transportation } \\
\text { period }\end{array}$ & $\begin{array}{c}\text { Plant } \\
\text { operational } \\
\text { period }\end{array}$ & $\begin{array}{c}\text { Weighted } \\
\text { results }\end{array}$ \\
\hline GWP & 0.48 & 0.049 & 0.012 & 0.000 & 0.060 \\
AP & 0.25 & 0.066 & 0.011 & 0.216 & 0.293 \\
POCP & 0.05 & 0.005 & 0.003 & 0.000 & 0.007 \\
HTP & 0.13 & 0.081 & 0.013 & 0.259 & 0.353 \\
SWP & 0.09 & 0.000 & 0.000 & 0.007 & 0.008 \\
In total & 1 & 0.199 & 0.038 & 0.483 & 0.721 \\
\hline
\end{tabular}




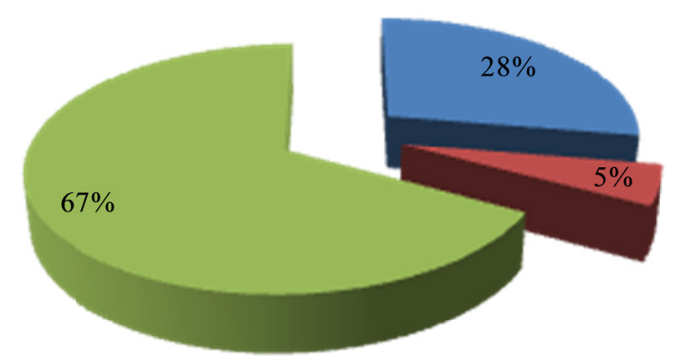

- Raw material acquisition $=$ Transportation $=$ Power generation

Figure 5. The share of environmental impacts from different processes

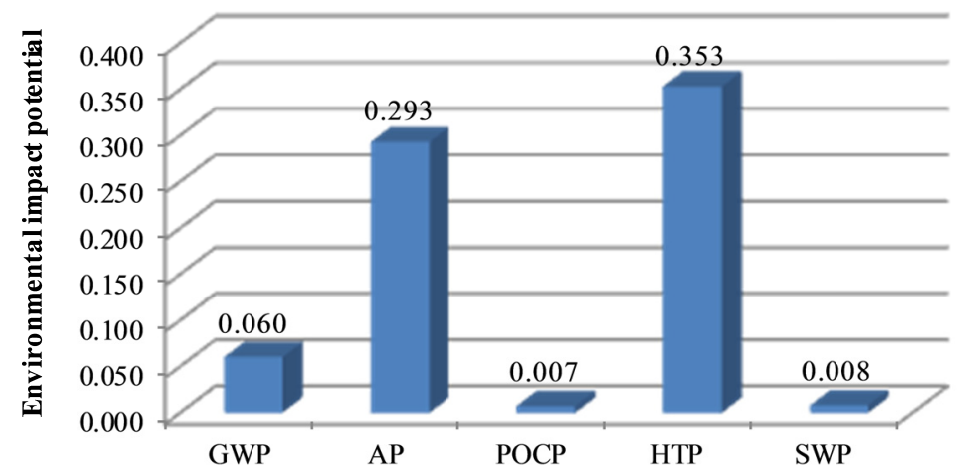

Figure 6. Weighted assessment results of life cycle environmental impact potential

\subsubsection{Analysis and Discussion About Life Cycle Assessment}

(1) Improvement assessment of life cycle

As is shown in Figure 5, among three processes of the whole system, power generation brings the most environmental impacts. When selecting the plant address, because of the consideration of fuel acquisition, all the collection stations supplying corn straw are near to the plant, which contributes to fewer impacts of transportation process. During agricultural production period, this article makes distributions of energy input and pollutant emission in agricultural production period according to the economic value. Because the distribution proportion is determined as $10 \%$ that is not so large, it does not bring substantial environmental impacts to involve the planting of corn straw into the life cycle boundary.

Among all the environmental impacts, Health Toxicity and Acidification which results from the emission of $\mathrm{CO}$, $\mathrm{NOx}$ and $\mathrm{SO}_{2}$ account for larger proportion. Even though low-nitrogen combustion technology has already been adopted and the height of exhaust pipe has been augmented, environmental impacts are still notable. Besides, the use of fertilizers during straw plating period contributes to the emission of NOx and SOx. Taking into consideration of carbon cycle of biomass, namely the neglect of $\mathrm{CO}_{2}$ emitted by straw combustion during power plant operational period, greenhouse gases of biomass power generation system mainly come from agricultural production period and transportation period. Photochemical Ozone Creation and Solid Waste are endowed with small weights and the pollutants don't have high concentration, leading to fewer impacts. Therefore when improving environmental impacts, the technologies and measures to lower the concentration of $\mathrm{CO}$, NOx and $\mathrm{SO}_{2}$ should be focused on to reduce the impacts of health toxicity and acidification.

(2) Comparison with thermal power generation system

Taking reference to the research of LCA on thermal power generation system (the calculation of pollutant emission and energy consumption on average level of China) done by Di Xianghua and Nie Zuo (Di \& Nie, 
2005), the emission amount of pollutants of thermal power generation system by generating $10000 \mathrm{kWh}$ electricity can be obtained and the environmental impacts brought by the pollutants can be calculated.

Table 20. Emission amount of pollutants of thermal power generation system

Unit: $\mathrm{kg} / 10^{4} \mathrm{kWh}$

\begin{tabular}{ccccccc}
\hline Pollutants & $\mathrm{CO}_{2}$ & $\mathrm{SO}_{2}$ & $\mathrm{NOx}$ & $\mathrm{CO}$ & $\mathrm{CH}_{4}$ & Dust \\
\hline Emission amount & 10700 & 99.3 & 64.6 & 15.5 & 26 & 202 \\
\hline
\end{tabular}

Table 21. Weighted assessment results of life cycle environmental impact potential of thermal power generation system

\begin{tabular}{ccc}
\hline Environmental impacts & Weight & Weighted results \\
\hline GWP & 0.48 & 1.768 \\
AP & 0.25 & 20.072 \\
POCP & 0.05 & 1.245 \\
HTP & 0.13 & 1.226 \\
SWP & 0.09 & 1.010 \\
In total & 1 & 25.321 \\
\hline
\end{tabular}

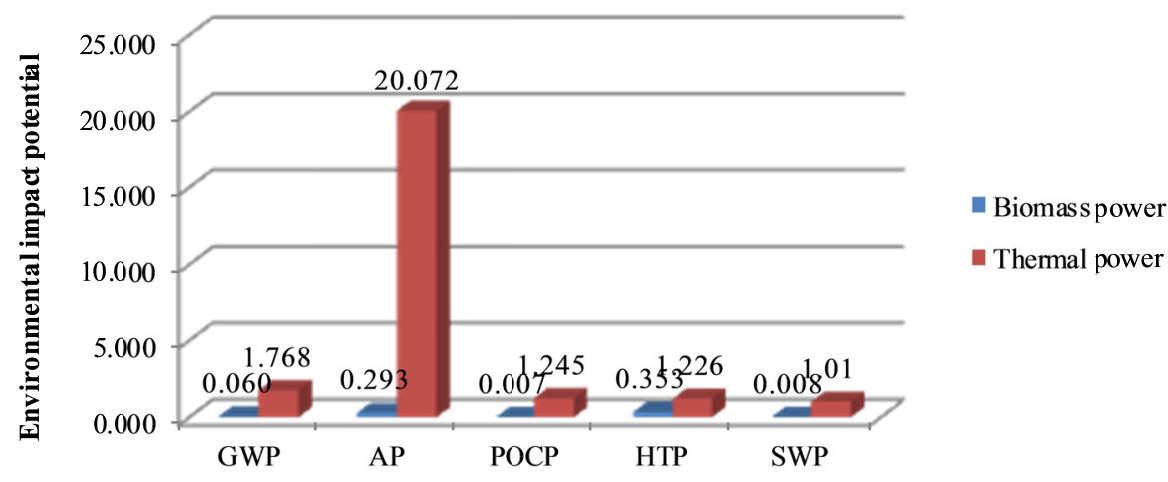

Figure 7. Comparison of environmental impacts of biomass power generation system and thermal power generation system

Illustrated by Figure 7, we can clearly see that total environmental impact burden of thermal power generation system is 25.321 , which is much larger than 0.721 of biomass power generation system. Acidification potential is the largest due to the combustion of coal containing high amount of sulfur.

\subsection{Life Cycle Cost Analysis of Biomass Power Generation System}

\subsubsection{General Cost Analysis}

General cost of biomass power generation system mainly consists of fuel cost, staff salaries, maintenance cost, material cost, management cost and depreciation cost. 
Table 22. Cost structure of biomass power generation system

Unit: yuan $/ 10^{4} \mathrm{kWh}$

\begin{tabular}{cc}
\hline Costs & Value \\
\hline Fuel cost & 2420 \\
Labor cost & 190 \\
Maintenance cost & 280 \\
Materials cost & 570 \\
Management cost & 70 \\
Depreciation cost & 710 \\
Cost per $10^{4} \mathrm{kWh}$ & 4240 \\
\hline
\end{tabular}

Cost structure of biomass power generation system shows that its general cost is 4240 yuan $/ 10^{4} \mathrm{kWh}$. Average general cost of thermal power generation system is 3250 yuan $/ 10^{4} \mathrm{kWh}$ (Chinese Energy, 2012). Compared with thermal power generation system, the cost of biomass power generation system is higher. And among all the costs, fuel cost accounts for more than $50 \%$. Several reasons are responsible for the high cost of biomass power generation system: (1) Higher investment in advanced equipments; (2) Lower electricity generation efficiency and high demand of fuels; (3) Higher transportation cost of fuels due to corn straw's large volume.

\subsubsection{Environmental Cost Analysis}

Table 23. Environmental cost account of biomass power generation system

\begin{tabular}{cccc}
\hline Pollutants & $\begin{array}{c}\text { Environmental } \\
\text { value(yuan } / \mathrm{kg})\end{array}$ & $\begin{array}{c}\text { Emission } \\
\text { amount }\left(\mathrm{kg} / 10^{4} \mathrm{kWh}\right)\end{array}$ & $\begin{array}{c}\text { Environmental } \\
\text { cost }\left(\mathrm{yuan} / 10^{4} \mathrm{kWh}\right)\end{array}$ \\
\hline $\mathrm{CO}_{2}$ & 0.023 & 978.488 & 22.5 \\
$\mathrm{CO}$ & 1 & 3.088 & 3.1 \\
$\mathrm{NOx}$ & 8 & 29.972 & 239.8 \\
$\mathrm{SO}_{2}$ & 6 & 21.163 & 127.0 \\
$\mathrm{PM}_{10}$ & 2.2 & 1.535 & 3.4 \\
In total & & & 395.7 \\
\hline
\end{tabular}

Table 24. Environmental cost account of thermal power generation system

\begin{tabular}{cccc}
\hline Pollutants & $\begin{array}{c}\text { Environmental } \\
\text { value(yuan/kg) }\end{array}$ & $\begin{array}{c}\text { Emission } \\
\text { amount }\left(\mathrm{kg} / 10^{4} \mathrm{kWh}\right)\end{array}$ & $\begin{array}{c}\text { Environmental } \\
\text { cost(yuan/10 }\end{array}$ kWh) \\
\hline $\mathrm{CO}_{2}$ & 0.023 & 10700 & 246.1 \\
$\mathrm{CO}$ & 1 & 15.5 & 15.5 \\
$\mathrm{NOx}$ & 8 & 64.6 & 516.8 \\
$\mathrm{SO}_{2}$ & 6 & 99.3 & 595.8 \\
$\mathrm{PM}_{10}$ & 2.2 & 202 & 444.4 \\
In total & & & 1818.6 \\
\hline
\end{tabular}

The results show that environmental cost of biomass power generation system is $395.7 \mathrm{yuan} / 10^{4} \mathrm{kWh}$ and environmental cost of thermal power generation system is 1818.6 yuan $/ 10^{4} \mathrm{kWh}$, which is much larger. Due to high amount of pollutants emission in transportation process of coal and the emission of high concentrations of $\mathrm{SO}_{2}$ and NOx in operational process of plant, thermal power generation system produces more serious impacts to environment that generates higher environmental cost. 


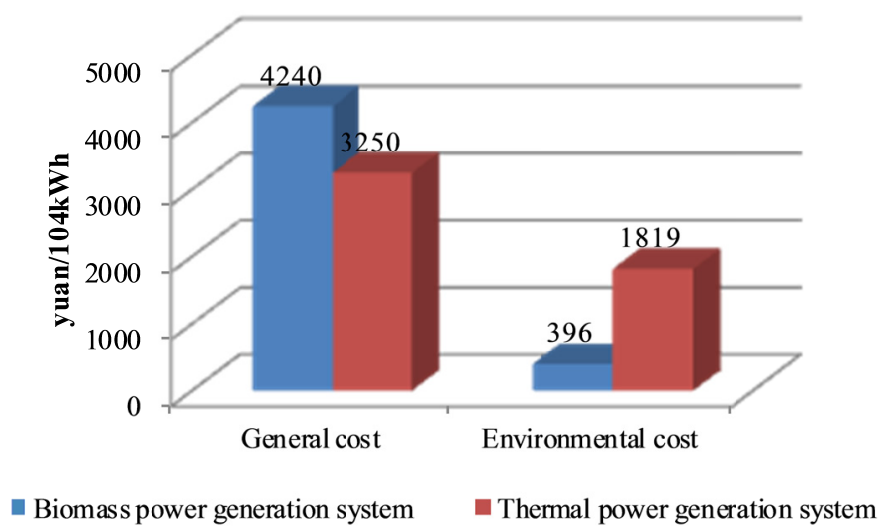

Figure 8. Comparison of life cycle cost of biomass power generation system and thermal power generation system

Compared with thermal power generation system, biomass power generation system has higher general costs however the environmental cost is much lower. When doing program investment, economic benefit is a key factor that affecting decision-making. Current evaluations of biomass power generation system mainly focus on economic benefit without taking environmental benefit into consideration. Since the internalization of external environmental cost is ignored, environmental advantages of biomass power generation system cannot be reflected compared with conventional thermal power generation system.

\section{Conclusions}

By estimating the biomass resources from four sources, this article obtained the total amount of biomass energy in Jilin Province, an amount that can be accounted for nearly 1/4 of total energy consumption in Jilin Province in 2011, which shows the potential of biomass utilization in mitigating the energy crisis. Farming is the biggest source of biomass energy in Jilin Province providing the major development direction of biomass industries.

With LCA of biomass power generation system, environmental advantages of biomass utilization is shown and proved compared with the utilization of conventional fossil energy. The comparison of general cost and environmental cost between biomass energy utilization and conventional fossil energy utilization further shows the environmental advantages of biomass utilization and the significance of internalization of environmental cost.

\section{References}

Bi, Y. (2010). Study on straw resources evaluation and utilization in China. Chinese Academy of Agricultural Sciences.

Chinese Energy. (2012). Reduction of the cost of thermal power generation. Retrieved March 9, 2012, from http://energy.gscn.com.cn/system/2012/03/09/010014595.shtml

Ding, J. (2000). The pollution of poultry and animal feces and the countermeasures in Guangzhou. Research of Environmental Sciences, 13(3), 57- 59.

Di, X., \& Nie, Z. (2005). Life Cycle inventory of fuel consumption of thermal power generation in China. Chinese Environmental Sciences, 25(5), 632-635.

$\mathrm{Hu}, \mathrm{Z}$. (2006). Life Cycle Assessment and multi-objective optimization of biodiesel for vehicles. Tongji University.

Huang, L. (2008). The research on forestry bio-energy utilization and its industry development in China. Beijing Forestry University.

Li, J., Ren D., \& Zhuang X. (2001). Assessment method of biomass energy and case study. Journal of Natural Resources, 16(4), 373- 380.

Liang, L., Chen, Y., \& Gao, W. (2009). Life Cycle Assessment on winter-wheat and summer-corn planting system in North China Plain. Agricultural Environmental Sciences, 28(8), 1773-1776. 
Liu, G., \& Shen, L. (2007). Quantitative evaluation and geographical distribution of biomass energy in China. Journal of Natural Resources, 22(1), 10-11.

Liu, J. (2010). Study on the initial conditions and Life Cycle Assessment on biomass energy utilization system. Beijing University of Chemical Technology.

Liu, L., \& Wang, X. (2008). LCA on biogas ecological agricultural mode. Chinese Biogas, 26(2), 17-24.

Liu, P., Na, W., \& Wang, X. (2010). Resource Evaluation and energy utilization analysis of main crops in Jilin Province. Jilin Agricultural Sciences, 35(5), 58-64.

Milbrandt, A. (2005). A geographic perspective on the current biomass resource availability in the United States. National Renewable Energy Laboratory. http://dx.doi.org/10.2172/861485

National Development and Reform Commission-Energy Research Institute. (2010). Chinese Biomass Energy Technological roadmap.

Nedo, Japan. (2010). White-book of Renewable Energy Technologies.

Peng, L., \& Wang, D. (2004). Estimation of annual quantity of total excretion from livestock and poultry in Chongqing Municipality. Transactions of the CSAE, 20(1), 288- 291.

Ren, F. (2011). Comprehensive evaluation of utilization efficiency of agricultural biomass resources, Soft Science, 25(9), 20-23.

Research Group of Chinese Forest Bio-energy. (2006). Cultivation and development potential survey of Chinese forest bio-energy resource. Chinese Forest Industry, 1, 12- 21.

Shi, Y. (2008). Chinese Renewable Energy Development Strategy-Biomass Volume. Chinese Electric Power Press.

Thornley, P., \& Cooper, D. (2008). The effectiveness of Policy instruments in Promoting bio-energy. Biomass and Bio-energy, 4, 119-128.

Wang, D. (2008). Study on the Comprehensive Evaluation about the Biomass Energy Systems. Huazhong University of Science \& Technology.

Wang, G., \& Ai, D. (2006). Introduction of New Energy. Beijing: Chemical Industry Press.

Wang, X. (1998). Feces of Livestock. Shanghai Jiaotong University Press.

Wenisch, S., \& Rousseaux, P. (2004). Analysis of technical and environmental parameters for waste to energy and recycling: Household waste case study. International Journal of Thermal Sciences, 43(5), 519-529. http://dx.doi.org/10.1016/j.ijthermalsci.2003.10.001

Yang, J., Xu, C., \& Wang, R. (2002). Methodology and Application of Product Life Cycle Assessment. Beijing Meteorological Press.

Yuan, Z., Wu, C., \& Huang, H. (2002). Research and development on biomass energy in China. International Journal of Energy Technology and Policy, 1, 108-144. http://dx.doi.org/10.1504/IJETP.2002.000806

Yuan, Z., Wu, C., \& Ma, L. (2005). Principles and Techniques of Biomass energy Utilization. Beijing: Chemistry Industrial Press.

Zhang, C. (2002). Current status and prospects of agricultural waste recycling technology. Environmental Protection, 1, 22-23.

Zhao, L. (2011, August 22). Biomass energy production by the end of $12^{\text {th }} 5$-year plan in Jilin. Chinese Construction News: Energy Saving and Technologies (p. A5).

\section{Copyrights}

Copyright for this article is retained by the author(s), with first publication rights granted to the journal.

This is an open-access article distributed under the terms and conditions of the Creative Commons Attribution license (http://creativecommons.org/licenses/by/3.0/). 